Buxron, A. (1952). J. gen. Microbiol. 7, 268-286.

\title{
On the Transference of Bacterial Antibodies from the Hen to the Ghick
}

\author{
BY A. BUXTON* \\ Animal Health Trust, Poultry Research Station, Houghton, Huntingdon
}

SUMMARY : Agglutinins against Salmonella pullorum and Salm. typhi (strain O 901) were induced in hens by intravenous inoculation with killed suspensions and were transferred to the yolks of their eggs. This transference of antibody continued throughout a laying season of about 280 days, and the relationship between the agglutinin titres of sera and yolks was not close. The titres of yolks seldom rose above 160 even when those in the serum were 2560 and 5120, whereas the agglutinin levels of developing ovules from hens naturally infected with Salm. pullorum were about the same in the related sera.

The sera and egg yolks of hens vaccinated with killed Salm. pullorum or infected with Salm. gallinarum contain a non-agglutinating antibody. The titres of nonagglutinating antibody in sera and in related egg yolks were about equal when hens were inoculated intravenously; very little antibody was demonstrable in fresh egg yolks after intramuscular or subcutaneous administration. Hens infected with $\mathbf{S a l m}$. gallinarum by the mouth yielded high yolk titres of agglutinating and non-agglutinating antibodies and these titres were maintained at a high level throughout the experimental period of $\mathbf{4 7 4}$ days. The results suggest that some of the antibody in egg yolk is formed in the follicular epithelium of the developing ovule or in the yolk material itself.

A passive immunity to Salm. pullorum is transferred from vaccinated hens to their chicks by the egg yolks and antibodies pass from yolk to embryonic serum from about the 11th day of incubation. The titres in the serum of the newly hatched chick are about the same as in the egg yolk before incubation and they decrease rapidly during the first 3 days and have almost disappeared by the 17th day; from the 8 th day until the 17 th day non-agglutinating antibodies alone are demonstrable. Antibodies are absorbed from the yolk through the vitelline and hepatic portal circulations and little or none is transferred by the yolk stalk and the chick's intestine.

Tetanus antitoxin (Ramon, 1928), diphtheria antitoxin (Jukes, Fraser \& Orr, 1934; Fraser, Jukes, Branion \& Halpern, 1934), neutralizing antibodies to Newcastle disease virus (Brandly, Moses, Jungherr, Jones \& Tizzer, 1946), antibodies to fowl plague (Schmidt, Ørskov \& Steinberg, 1936) and antibodies to the Rous sarcoma (Andrewes, 1939) may pass from the hen or duck to the egg. Agglutinins against Salmonella pullorum may be present in yolk from eggs of infected hens, but no comparison has been made between their concentration in hens' sera and egg yolks. Grasset (1929) could not detect any transference of passive immunity to the embryo after vaccination of hens with diphtheria toxin, and Garinei (1945) reported that antibodies against pseudo-fowl plague were not passed from the hen to the egg and chick. The transference of antibodies against Newcastle disease, fowl plague (Brandly et al. 1946; Levine \& Fabricant, 1950) and infectious bronchitis (Jungherr \& Terrell, 1948; Hofstad \& Kenzy, 1950) has been observed.

* Now at Dept. of Veterinary Pathology, University of Liverpool. 
The observations herewith reported are concerned with the conditions under which agglutinating and non-agglutinating antibodies against Salm.pullorum, Salm. gallinarum and Salm. typhi (strain O 901) are transferred from the hen to the egg and their passage from the egg to the developing embryo.

\section{MATERIALS AND METHODS}

Pure Rhode Island Red pullets and Barred Rock pullets kept on grass were used for the vaccination experiments.

The suspensions of Salm. pullorum and Salm. typhi (strain O 901) were prepared by adding $150 \mathrm{ml}$. ethanol to $50 \mathrm{ml}$. saline washings of a $48 \mathrm{hr}$. growth; this was shaken twice daily for 2 days and stored at room temperature and a small quantity of the deposit was resuspended in saline as required.

Intravenous inoculations were made into the brachial vein, intramuscular inoculations into the thigh muscles and subcutaneous inoculations under the skin of the breast muscles; the quantities were $0 \cdot 2 \mathrm{ml}$. of a suspension containing approximately $2 \times 10^{9}$ bacteria $/ \mathrm{ml}$.

The egg yolk for agglutination tests was withdrawn with a syringe after the egg shell and membranes were removed from over the air-space and the albumen discarded; $1 \mathrm{ml}$. was added to $4.0 \mathrm{ml}$. of $8.0 \%(\mathrm{w} / \mathrm{v})$ saline and the mixture was shaken and stood for $24 \mathrm{hr}$. Serial twofold dilutions of the transparent fluid below the fat were made in $8.0 \%(\mathrm{w} / \mathrm{v})$ saline and to $0.3 \mathrm{ml}$. of each dilution was added $0.3 \mathrm{ml}$. bacterial suspension. This gave a final concentration of approximately $4 \cdot 4 \%(\mathrm{w} / \mathrm{v})$ saline which kept the yolk proteins in suspension.

Livetin was prepared by mixing $10 \mathrm{ml}$. of egg yolk with $30 \mathrm{ml}$. ether; this was shaken and after a few minutes the ether was withdrawn. This extraction was repeated 5 times, finally the ether was removed by centrifuging. To the egg yolk was added $36 \mathrm{ml} .0 \cdot 85 \%(\mathrm{w} / \mathrm{v})$ saline and the mixture stored at $5^{\circ}$ overnight. After centrifugation at 4000 r.p.m. for $30 \mathrm{~min}$. an equal volume of saturated ammonium sulphate was added to the supernatant. The livetin precipitated overnight at $5^{\circ}$ and was concentrated by centrifugation at 4000 r.p.m. for $20 \mathrm{~min}$. This precipitate was resuspended in saline to give a volume of $20 \mathrm{ml}$., and after further precipitation by half saturation with ammonium sulphate it was suspended in $0.85 \%$ saline. Any residual ammonium sulphate was removed by dialysis and the final volume of livetin made up to $24 \mathrm{ml}$.

Anti-livetin serum was prepared in rabbits by giving a series of intravenous inoculations of livetin; precipitin titres of $1 / 10,000$ were obtained and the sera were stored at $5^{\circ}$ without preservative.

Non-agglutinating antibodies were detected as follows: after serum samples had been tested for agglutinins, the tubes in which agglutination had not occurred were centrifuged for $15 \mathrm{~min}$. at 4000 r.p.m.; the supernatant fluid was discarded and the antigen washed twice in saline. This was resuspended to its original volume in saline and an equal volume of anti-livetin rabbit serum diluted $\mathbf{1} / 40$ was added. The tubes were incubated overnight at $52^{\circ}$. A similar technique was used for the detection of non-agglutinating antibodies in yolk, 
except that yolk-sensitized suspensions of antigen were washed with $8 \%(w / v)$ saline.

Blood samples were collected from developing embryos by a method similar to that described by Beveridge \& Burnet (1946) for intravenous inoculation. At least $0.2 \mathrm{ml}$. of blood was withdrawn from each egg and cellulose tape was applied over the area; the egg was then replaced in the incubator. Considerable haemorrhage sometimes occurred after the removal of the needle and the embryos died. In many other cases development continued until the 21 st day but the embryos adhered to the shell membrane and failed to hatch. Blood samples were taken in this way from the 11th to the 17th days of incubation but after the 18th day the blood vessels were not easily seen by candling because of the size of the embryo. Moreover, the partial collapse of the blood vessels in the chorio-allantoic membrane made it difficult to withdraw sufficient blood.

Yolk samples were taken with a Pasteur pipette through an area of the chorio-allantoic membrane devoid of large blood vessels. Cellulose tape was applied over the areas of shell that had been removed and the eggs were returned to the incubator and kept with the perforated areas uppermost. There was a danger of a fatal leakage of allantoie fluid if the eggs were turned. There was a high mortality among embryos which had had yolk samples taken and only in a small number was it possible to take additional samples of sera and yolks at later stages. During the latter part of the work fertile eggs were incubated and removed from the incubator in groups at different stages of development; samples of blood and yolk were taken and the embryos sacrificed.

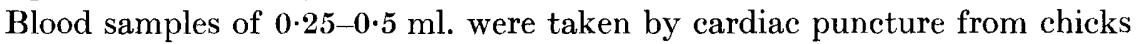
during the first 14 days after hatching, using an all-glass syringe with a 27 gauge $\frac{1}{2} \mathrm{in}$. needle. Chicks of 14 days of age or older were bled from the brachial vein.

A drop technique was employed with small quantities of serum and the dilutions were made directly into the agglutination tubes; the first dilution was $1 / 10$ and incubation was at $52^{\circ}$ in a water-bath.

\section{RESULTS}

The Passage of Agglutinins from the Hen to the Egg

Agglutinins in the sera and developing ovules of hens naturally

infected with Salm. pullorum

This experiment was designed to confirm that yolk material from birds naturally infected with Salm. pullorum contain agglutinins (Frank \& Edgington, 1937; Stoilowa, 1938), and to compare the titres in the developing ovules and sera.

Samples of serum were taken from four laying hens which were positive to the pullorum test and were from a flock in which pullorum disease existed. They were slaughtered and four or five of the largest ovules removed. The sera and yolk material from the ovules were tested for agglutinins and cultures for Salm. pullorum, using sodium selenite medium and deoxycholate citrate agar, were made from ovarian tissue and yolk material. The results are given 
in Table 1, which shows that the agglutinin titres of the individual ovules, including one known to be infected, were nearly the same as the related sera. The infected ovule showed the typical degeneration associated with chronic ovarian infection with Salm. pullorum.

Table 1. Agglutinin titres of sera and ovules against Salm. pullorum and the results of cultural examination

$\begin{array}{cllll}\text { No. of hen } \ldots & 1971 & 4890 & 1926 & 4724 \\ \text { Serum } & 650 & 750 & 650 & 650 \\ 01 & 650^{*} & 500^{*} & 500^{*} & 325^{*} \\ 02 & 650^{*} & 650^{*} & 500^{*} & 500^{*} \\ 03 & 650^{*} & 325^{*} & 500^{*} & 500^{*} \\ 04 & 650^{*} & 500^{*} & 500^{*} & 500^{*} \\ 05 & 500+\$ & - & - & - \\ \text { OM } & \S & \S & * & \end{array}$

$01,02=$ individual ovules.

$\mathbf{O M}=$ ovarian material after serological and cultural examinations had been made.

* Salm. pullorum not isolated.

$\dagger$ Yolk material from formed egg in oviduct.

$\ddagger$ Ovule showing typical Salm. pullorum degeneration.

$\S$ Salm. pullorum isolated.

\section{Agglutinins in the sera and yolks of eggs of birds inoculated intravenously with killed Salm. pullorum}

This next experiment was to observe whether results similar to the previous experiment would be obtained from hens inoculated with killed Salm. pullorum, and whether the transfer of antibodies from the hen to the egg continued throughout the whole laying season.

Six young Rhode Island Red hens (nos. 1498, 1499, 1500, 1501, 1502 and 1503) were vaccinated and four were kept as controls. Further doses of vaccine were given at intervals; the hens were bled periodically and their sera and egg yolks tested for agglutinins. The wide variation in the titres of egg yolks is shown in Figs. 1 and 2. With the exception of hen no. 1499 (Fig. 2) the initial serum titres were much higher than the corresponding yolk titres; this was marked in hen no. 1503 where the initial serum titre was just above 10,240. Hen no. 1500 (Fig. 1) laid eight eggs during the first 60 days of the experiment, agglutinins were not demonstrable in any of the yolks, although the serum titres varied from about $1 / 80$ to $1 / 320$ during this time. With few exceptions yolk titres were never above $1 / 160$, and in most cases there was considerable variation between consecutive yolks, particularly during periods of vaccination. All tests on the sera and yolks from control birds were negative.

\section{Agglutinins in the sera and yolks of eggs of birds inoculated intravenously with killed Salm. typhi (strain O 901)}

A similar experiment to the one just described was made using Salm. typhi (strain O 901) in place of Salm. pullorum as a vaccine. Though there is a close antigenic relationship between these organisms, a suspension of Salm. typhi was found to be more sensitive to agglutinins against Salm. pullorum in 
hen sera than a suspension of the homologous bacterium. Suspension:; of each organism were used in the tests made.

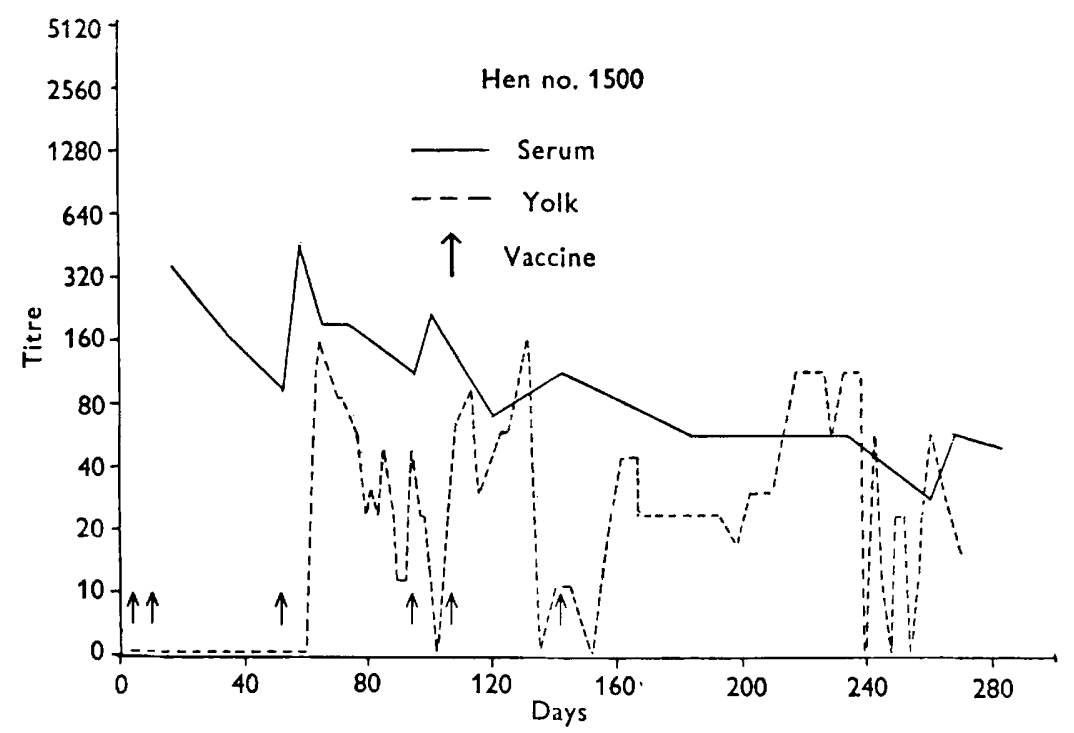

Fig. 1

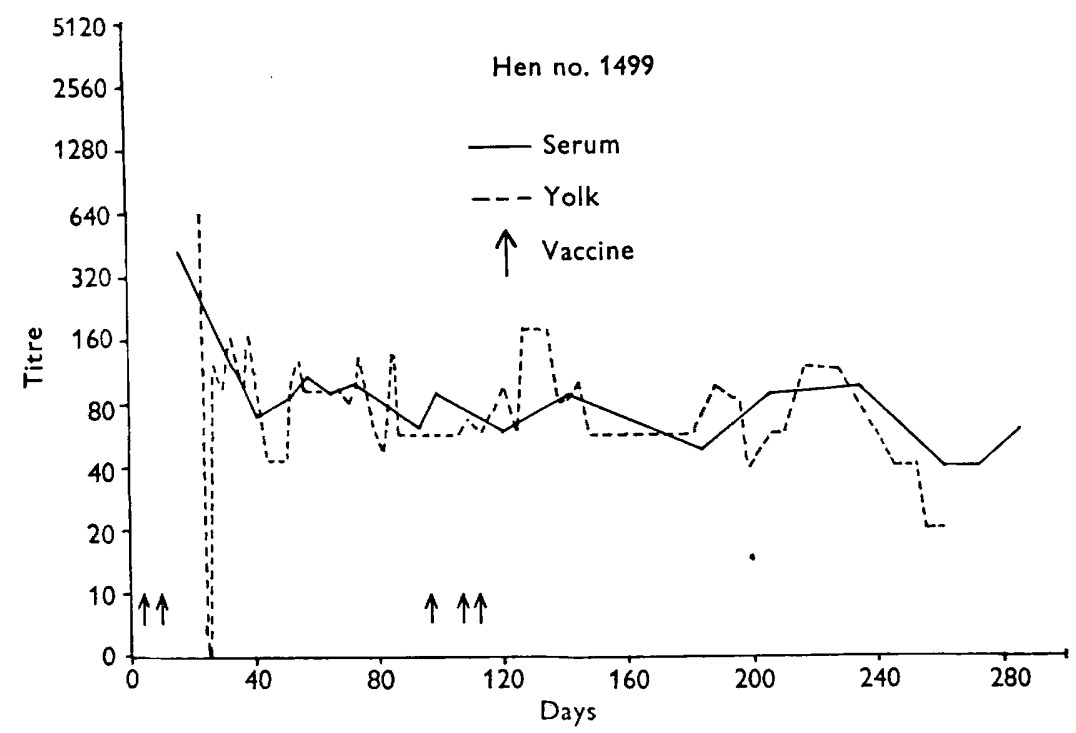

Fig. 2

Figs. 1-2. Agglutinins against Salm. pullorum in the sera and yolks of eggs from hens after intravenous inoculation with killed Salm. pullorum.

Six Rhode Island Red hens (nos. 1545, 1546, 1547, 1548, 1549 and 1550) were inoculated intravenously at intervals with killed Salm. typhi (strain O 901); four unvaccinated hens were kept as controls. One hen (no. 1548) died from 
lymphomatosis, and hen no. 1549 laid only a few eggs during the first weeks of the experiment. The results obtained from two of the hens (nos. 1546 and 1550) are shown in Figs. 3 and 4. In all cases the titres of the yolks against the

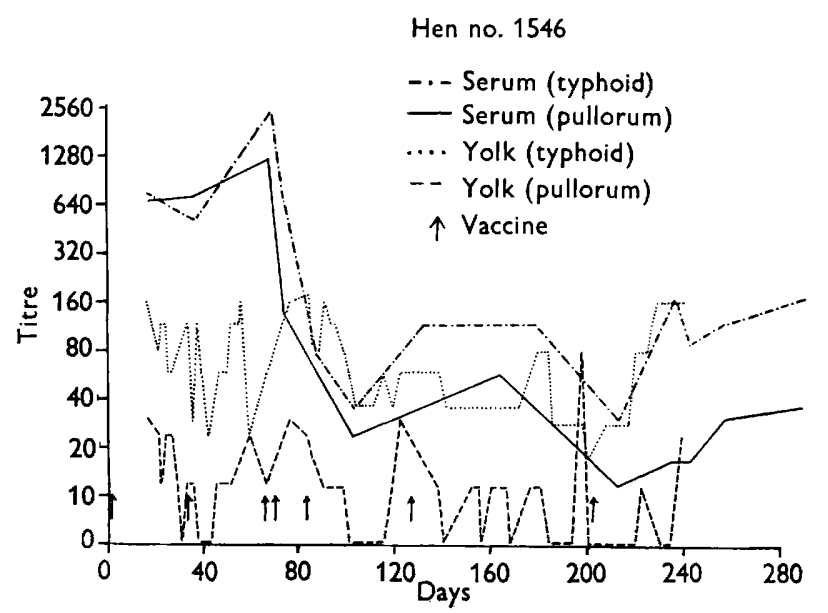

Fig. 3

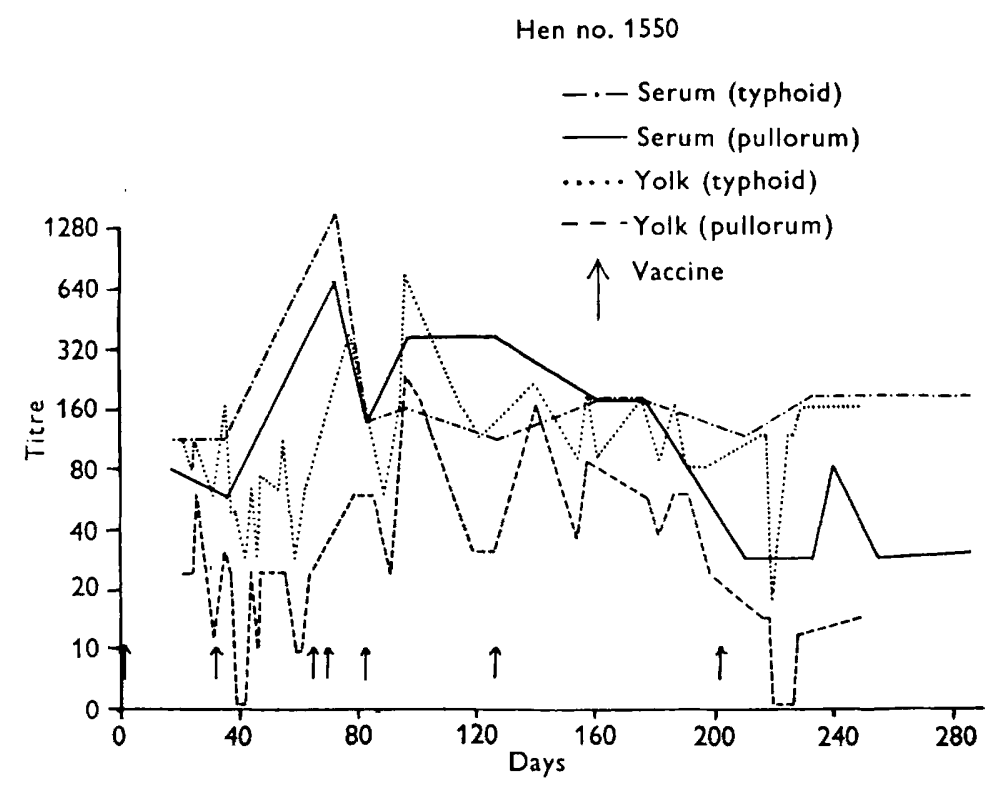

Fig. 4

Figs. 3-4. Agglutinins against Salm. pullorum and Salm. typhi in the sera and yolks of eggs from hens after intravenous inoculation with killed Salm. typhi (strain O 901).

typhoid suspension were higher than against the pullorum suspension and this was most apparent in hen no. 1546 (Fig. 3). The serum titres showed a greater similarity to each other than the corresponding yolk titres, and those against 
the typhoid bacillus were higher. This was reversed in hen no. 1550 during the period of 80-160 days when the titre against Salm. pullorum was double that against Salm. typhi. Although there was no comparable reversion in egg yolk titres they did approximate more closely to each other in this bird during that period.

The Passage of Non-agglutinating Antibodies from the

Hen To THE EGG

Non-agglutinating antibodies in the sera and yolks of eggs of

hens inoculated intravenously with killed Salm. pullorum

Four Barred Rock hens (nos. 1000, 1003, 1004 and 1006) were inoculated intravenously with killed Salm. pullorum on the 1st and 8th days of the experiment. Samples of serum and egg yolk were tested for agglutinating and non-agglutinating antibodies, and the results from one bird (no. 1003) are given in Fig. 5.

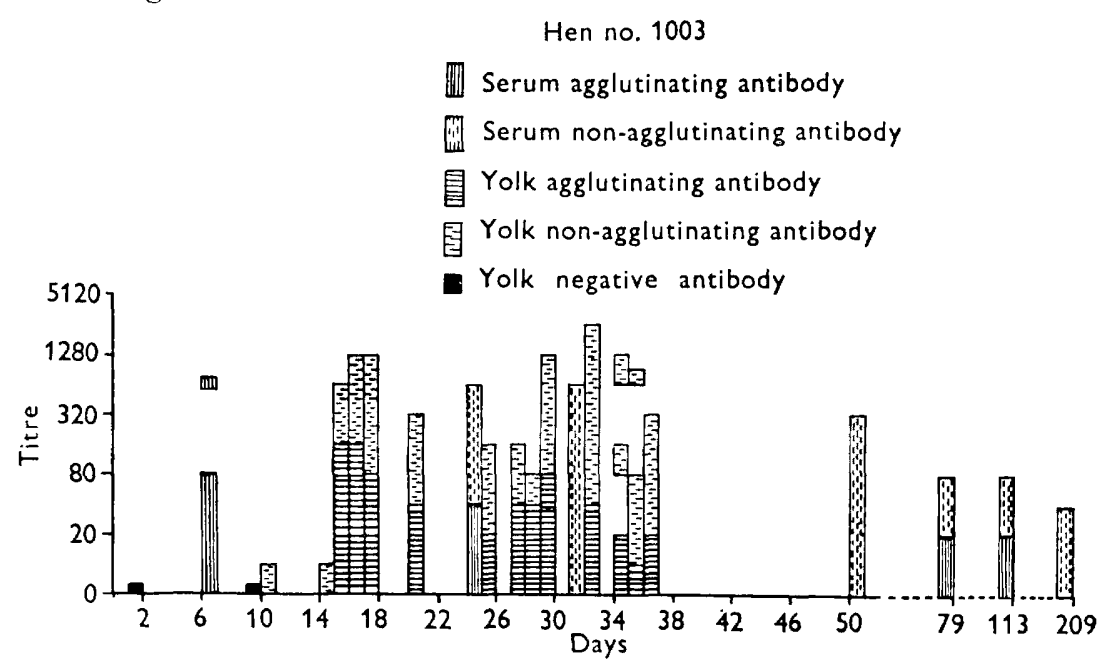

Fig. 5. Agglutinating and non-agglutinating antibodies in the serum and eggs from a hen after intravenous inoculation with killed Salm. pullorum.

Antibody tests on serum from hen no. 1004 are given in Table 2 for comparison with hen no. 1003. The serum titres of the four hens were rarely below $1 / 160$; with the exception of hen no. 1003 which was $1 / 80$ and $1 / 40$ from the 79th to the 209th day.

Serum agglutinins were demonstrable by the 7 th day and non-agglutinating antibodies in higher titres than agglutinins were observable on the 25th day, and were present in all samples up to the 209th day. No agglutinins occurred in the sera of hen no. 1003, when non-agglutinating antibody titres of $1 / 640$, $1 / 320$ and $1 / 40$ were demonstrated on the 32nd, 51st and 209th days, respectively.

The earliest time at which antibodies were detected in egg yolk varied; nonagglutinating antibodies alone were detected in yolks laid by hen no. 1006 on the 6th and 8th days after the first inoculation. It was 15 and 16 days 
respectively, before egg yolks from birds 1000 and 1003 contained antibody titres approximating to those in their sera. The average titre of non-agglutinating antibody in egg yolks remained fairly constant, and showed a close relation to similar titres in serum.

Agglutinin titres in egg yolks varied and were lower than corresponding serum titres; in contrast to serum samples, non-agglutinating antibodies in yolks were demonstrable before agglutinins.

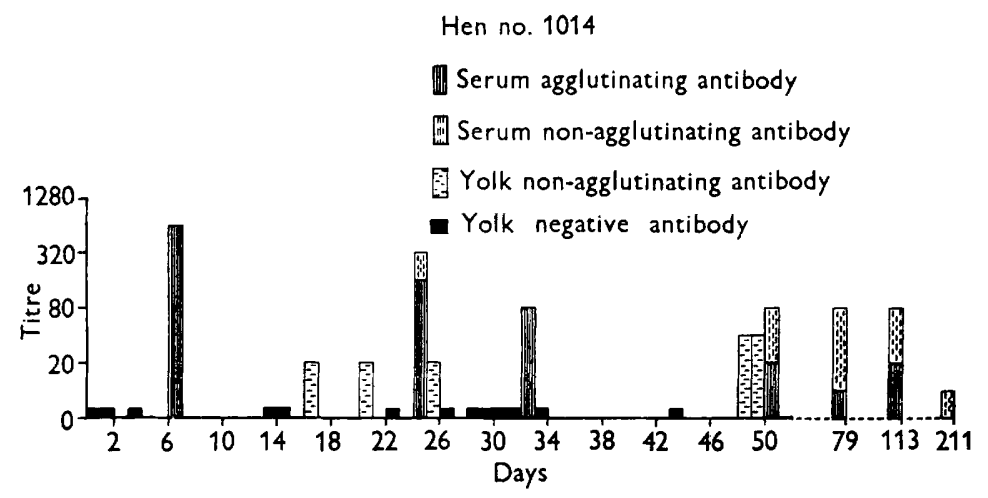

Fig. 6. Agglutinating and non-agglutinating antibodies in the serum and egg yolks from a hen after subcutaneous inoculation with killed Salm. pullorum.

The non-agglutinating antibodies from the two eggs laid by hen no. 1003 on the 35th and 36th days showed a zone effect; this phenomenon occurred only with these eggs and with a sample of serum from the same hen, taken on the 7 th day.

Non-agglutinating antibodies in the sera and yolks of eggs from hens inoculated subcutaneously with killed Salm. pullorum

Four Barred Rock hens (nos. 1002, 1007, 1014 and 1020) were inoculated subcutaneously with killed Salm. pullorum on the 1st and 8th days of the experiment. The sera and egg yolks from these birds were tested for agglutinating and non-agglutinating antibodies, and the results from one bird (no. 1014) are shown in Fig. 6.

The antibody content of the sera varied particularly during the latter half of the experiment. Two hens (nos. 1002 and 1007) maintained fairly constant serum titres throughout the whole period and were in contrast to hen no. 1014 and particularly hen no. 1020. The first samples taken from all the birds on the 7 th and 8 th days contained agglutinins only and were similar to those from the birds which had been inoculated intravenously. The non-agglutinating antibodies were demonstrable at variable times. In hens nos. 1007 and 1014 agglutinins predominated for the first 30 days, whereas from the 50th to the 80th days onwards the non-agglutinating antibodies were in excess. Nonagglutinating antibodies appeared earlier in samples from hens nos. 1002 and 1020. They were present in all samples from the 25th day except that from 
no. 1020 on the 113th day; this bird showed the greatest variation in the amount and type of antibody in its serum.

The eggs from these birds were tested for antibody content, and a small amount only was transferred from the hen to the egg yolk. A yolk titre of 1/20 was the highest recorded, although the serum titres at the time most of these eggs were laid varied from $1 / 80$ to $1 / 1280$. The type of antibody in the egg yolks was not constant and bore no relationship to the type of antibody in the related sera.

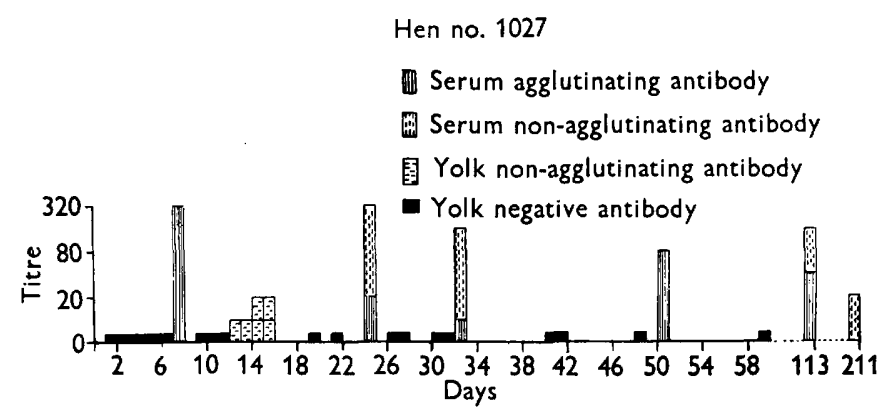

Fig. 7. Agglutinating and non-agglutinating antibodies in the serum and egg yolks from a hen after intramuscular inoculation with killed Salm. pullorum.

Non-agglutinating antibodies in the sera and yolks of eggs from hens inoculated intramuscularly with killed Salm. pullorum

Four Barred Rock hens (nos. 1022, 1027, 1038 and 1039) were inoculated intramuscularly with a suspension of killed Salm. pullorum on the 1st and 8 th days of the experiment. The results of antibody tests on the sera and yolks of eggs from hen no. 1027 are shown in Fig. 7. Hen no. 1039 laid only a few eggs during the first days of the experiment and it was not possible to compare its serum and yolk antibodies; the results of the antibody tests on the serum from this bird are included in Table 2 for comparison with hen no. 1027 (Fig. 7 ).

The agglutinating and non-agglutinating antibodies in the sera of all these birds were similar to those in hens inoculated subcutaneously. Serum titres were maintained at a level of at least $1 / 40$ during the first 113 days of the experiment. On the 7th day agglutinins only were present in all four sera, and this is comparable to the results obtained from the subcutaneously and intravenously inoculated groups.

The tests on egg yolks showed that only a little antibody was transferred from the hen to the yolk, and this was of the non-agglutinating kind; these results are similar to those obtained from subcutaneously inoculated hens.

Non-agglutinating antibodies in the sera and yolks from eggs of hens infected orally with living Salm. gallinarum

The purpose of this experiment was to observe the development of agglutinating and non-agglutinating antibodies in the sera of hens infected with live organisms, and to compare the results with those obtained from hens after 
inoculation with dead organisms by the intravenous, subcutaneous and intramuscular routes.

Four Brown Leghorn hens (nos. 1280, 1285, 1322 and 1324) aged 4 months were infected orally with $\mathbf{0 . 2} \mathrm{ml}$. of an $18 \mathrm{hr}$. broth culture of Salm. gallinarum. Serum samples were taken at intervals and tested for agglutinating and non-

Table 2. The agglutinating and non-agglutinating antibody titres of sera and egg yolks from immunized hens

\begin{tabular}{|c|c|c|c|c|c|c|c|c|}
\hline \multirow{3}{*}{$\begin{array}{l}\text { Days of } \\
\text { experi- } \\
\text { ment }\end{array}$} & \multicolumn{2}{|c|}{ Hen no. $1004^{*}$} & \multicolumn{2}{|c|}{ Hen no. $1039 \dagger$} & \multicolumn{2}{|c|}{ Hen no. 1324t } & \multicolumn{2}{|c|}{ Hen no. $1322 \ddagger$} \\
\hline & \multicolumn{2}{|c|}{ Serum } & \multicolumn{2}{|c|}{ Serum } & \multicolumn{2}{|c|}{ Serum } & \multicolumn{2}{|c|}{ Serum } \\
\hline & A & $\mathbf{N A}$ & A & $\mathbf{N A}$ & A & NA & A & $\mathbf{N A}$ \\
\hline 7 & 320 & $>320$ & 320 & $>320$ & 0 & 10 & 0 & 10 \\
\hline 20 & $\ldots$ & - & - & - & 40 & 80 & 320 & 640 \\
\hline 32 & 1,280 & 5,120 & 0 & 320 & 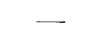 & - & - & Died \\
\hline 49 & - & - & - & $\ldots$ & 2,560 & 5,120 & 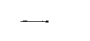 & - \\
\hline 113 & 40 & 640 & 20 & 80 & - & Died & - & - \\
\hline 265 & - & -- & $\ldots$ & - & - & - & $\longrightarrow$ & - \\
\hline 347 & - & - & - & $\longrightarrow$ & - & - & 一 & - \\
\hline 374 & - & - & - & $\longrightarrow$ & - & - & $\ldots$ & $\ldots$ \\
\hline 403 & - & -- & - & - & - & - & $\ldots$ & $\ldots$ \\
\hline 413 & - & - & - & - & 一 & - & - & - \\
\hline \multirow[t]{2}{*}{474} & - & - & - & 一 & 一 & 一 & - & - \\
\hline & \multicolumn{4}{|c|}{ Hen no. $1280 \ddagger$} & \multicolumn{4}{|c|}{ Hen no. 1285 } \\
\hline \multirow{2}{*}{$\begin{array}{l}\text { Days of } \\
\text { experi- } \\
\text { ment }\end{array}$} & \multicolumn{2}{|c|}{ Serum } & \multicolumn{2}{|c|}{ Yolk } & \multicolumn{2}{|c|}{ Serum } & \multicolumn{2}{|c|}{ Yolk } \\
\hline & $\mathbf{A}$ & NA & A & $\mathbf{N A}$ & A & NA & $\mathbf{A}$ & $\mathbf{N A}$ \\
\hline 7 & 80 & $>80$ & 一 & - & 20 & 80 & - & - \\
\hline 20 & 5,120 & 20,480 & - & $一$ & 320 & 5,120 & 一 & - \\
\hline 32 & - & - & $\longrightarrow$ & - & $\ldots$ & $\ldots$ & - & - \\
\hline 49 & 640 & 2,560 & - & - & 2,560 & 5,120 & - & - \\
\hline 113 & $\ldots$ & - & - & - & - & - & 一 & $\ldots$ \\
\hline 265 & 640 & 10,240 & -- & - & 160 & 2,560 & $\cdots$ & - \\
\hline 347 & 1,280 & 10,240 & 20,480 & 81,920 & 1,280 & 5,120 & 1,280 & 5,120 \\
\hline 374 & $\ldots$ & $\ldots$ & 10,240 & 163,840 & $\ldots$ & - & - & $-\cdots$ \\
\hline 403 & 2,560 & 10,240 & 10,240 & 163,840 & - & - & $\rightarrow$ & $\ldots$ \\
\hline 413 & - & - & - & - & - & - & 1,280 & 20,480 \\
\hline 474 & 10,240 & 81,920 & - & - & 2,560 & 20,480 & - & - \\
\hline & $\begin{array}{l}* \text { In } \\
\dagger \text { In } \\
+ \text { Or } \\
\mathbf{A}=\end{array}$ & $\begin{array}{l}\text { venous } \\
\text { muscul } \\
\text { infectio } \\
\text { lutinin }\end{array}$ & $\begin{array}{l}\text { noculatio } \\
\text { vith liv } \\
\mathbf{A}=\text { non }\end{array}$ & $\begin{array}{l}\text { killed s } \\
\text { on killed } \\
\text { g Salm. } \\
\text { agglutin }\end{array}$ & $\begin{array}{l}\text { ension } \\
\text { spensi }\end{array}$ & $\begin{array}{l}\text { alm. pu } \\
\text { Salm. } 1\end{array}$ & nim. & \\
\hline
\end{tabular}

agglutinating antibodies. Two hens (nos. 1322 and 1324) died after about 50 and 110 days respectively, from the infection with $\mathrm{Salm}$. gallinarum. The results of the antibody tests on the sera from these two birds are shown in Table 2. Seven days after infection their sera showed very low nonagglutinating antibody titres but both types of antibody were demonstrable on the 20th day. This early development of non-agglutinating antibody in hens after infection contrasts with the results obtained from inoculation of dead bacteria by the intravenous, subcutaneous and intramuscular routes. In these cases, agglutinins were the first antibodies to be detected in the sera. 
Two of the infected hens (nos. 1280 and 1285) survived the infection with Salm. gallinarum and the antibody content of their sera was tested during the period of 474 days. During the latter half of the experiment both birds came into lay and the yolks of their eggs were also tested for antibodies. These results are summarized in Table 2 . Serum titres were maintained at a high level throughout the period and the non-agglutinating antibody titre reached its highest level in each bird on the 474th day after infection. The agglutinating and non-agglutinating antibody titres were as high in egg yolks as the serum titres in hen no. 1285, and in hen no. 1280 they were of ten more than double the serum titres.

The Transference of Antibodies from the Egg to the Chick

The transference of antibodies from the yolk to the embryo

Fertile eggs were incubated, and samples of yolk and embryo serum taken at intervals between the 11th and 17th days of incubation. All samples were tested for agglutinating and non-agglutinating antibodies.

The results are given in Table 3 and show a variation in the rate at which antibodies are transferred from the egg yolk to the serum of the embryo

Table 3. The antibody titres of yolks and related embryonic sera in eggs at different periods of incubation

\begin{tabular}{|c|c|c|c|c|c|}
\hline \multirow{2}{*}{$\begin{array}{l}\text { Egg } \\
\text { no. }\end{array}$} & \multirow{2}{*}{$\begin{array}{c}\text { Day of } \\
\text { incubation }\end{array}$} & \multicolumn{2}{|c|}{ Yolk titre } & \multicolumn{2}{|c|}{ Serum titre } \\
\hline & & $\mathbf{A}$ & NA & $\mathbf{A}$ & NA \\
\hline 1 & 11 & 10 & 80 & 0 & 0 \\
\hline 2 & 11 & 10 & 80 & 0 & 10 \\
\hline 3 & 11 & 20 & 80 & 0 & 10 \\
\hline 4 & 11 & 640 & 1280 & 0 & 10 \\
\hline 5 & 11 & 80 & 320 & 0 & 10 \\
\hline 6 & 11 & 1280 & 5120 & 0 & 10 \\
\hline 7 & 11 & 160 & 320 & 0 & 160 \\
\hline 8 & 11 & nt & nt & $\mathbf{0}$ & 80 \\
\hline 9 & 11 & nt & nt & 0 & 20 \\
\hline 10 & 12 & 160 & 320 & 0 & 20 \\
\hline 11 & 12 & 40 & 40 & 0 & 20 \\
\hline 12 & 14 & 320 & 2560 & 0 & 40 \\
\hline 13 & 14 & 80 & 320 & 0 & 10 \\
\hline 14 & 14 & 320 & 2560 & 0 & 40 \\
\hline 15 & 15 & 40 & 80 & 0 & 5 \\
\hline 16 & 15 & 20 & 160 & 5 & 20 \\
\hline 17 & 15 & 40 & 320 & 0 & 10 \\
\hline 18 & 15 & 40 & 80 & 1280 & 1280 \\
\hline 19 & 17 & 1280 & 1280 & 40 & 320 \\
\hline 20 & 17 & 80 & 5120 & 0 & 5 \\
\hline 21 & 17 & 80 & 160 & 0 & 0 \\
\hline 22 & 17 & 80 & 640 & 0 & 1280 \\
\hline 23 & 17 & 40 & 80 & 10 & 20 \\
\hline 24 & 11) & 320 & 640 & $\left\{\begin{array}{l}160 \\
000\end{array}\right.$ & 160 \\
\hline & $17\}$ & & & $\{320$ & 640 \\
\hline 25 & $11\}$ & 320 & 640 & $\{80$ & 80 \\
\hline
\end{tabular}

$\mathbf{A}=$ agglutinating antibody $; \mathrm{NA}=$ non-agglutinating antibody $; \mathrm{nt}=$ not tested. 
Agglutinins were never demonstrated in embryo sera from the 11th to the 14th days of incubation, and were often absent in eggs examined from the 15 th to the 17th day. In most samples the presence of non-agglutinating antibodies alone was the first indication of the transference of immunity from the egg to the embryo.

The transference of antibodies from the yolk to the young chick

(1) First experiment. The eggs used were laid by three hens (nos. 1000, 1003 and 1006) which had been used in a previous experiment, and were collected 100-150 days after the hens had been inoculated intravenously with killed Salm. pullorum.

Table 4. Antibody titres in the sera of young chicks hatched from eggs of immune birds

\begin{tabular}{|c|c|c|c|c|c|c|c|}
\hline \multirow{2}{*}{$\begin{array}{c}\text { No. of } \\
\text { parent } \\
\text { bird }\end{array}$} & \multicolumn{2}{|c|}{ Parent serum } & \multicolumn{2}{|c|}{ Parent yolk } & \multirow{2}{*}{$\begin{array}{l}\text { No. of } \\
\text { chick }\end{array}$} & \multirow{2}{*}{$\begin{array}{l}\text { Age of } \\
\text { chick } \\
\text { (days) }\end{array}$} & \multirow{2}{*}{$\begin{array}{c}\text { Chick } \\
\text { serum } \\
\text { (NA) }\end{array}$} \\
\hline & $\mathbf{A}$ & $\mathbf{N A}$ & $\mathbf{A}$ & NA & & & \\
\hline 1000 & 320 & 1,280 & 20 & 320 & $\begin{array}{l}1 \\
2\end{array}$ & $\begin{array}{l}1 \\
1\end{array}$ & $\begin{array}{l}40 \\
20\end{array}$ \\
\hline 1003 & - & - & - & 一 & $\begin{array}{l}3 \\
4\end{array}$ & $\begin{array}{l}1 \\
1\end{array}$ & $\begin{array}{l}20 \\
10\end{array}$ \\
\hline 1006 & - & $\rightarrow$ & $\ldots$ & - & 5 & 1 & 10 \\
\hline 1000 & $\ldots$ & 一 & 一 & $\longrightarrow$ & 6 & 8 & 20 \\
\hline 1003 & - & - & 10 & 80 & $\begin{array}{l}7 \\
8\end{array}$ & $\begin{array}{l}8 \\
8\end{array}$ & $\begin{array}{l}20 \\
10\end{array}$ \\
\hline 1006 & - & - & - & - & $\begin{array}{r}9 \\
10 \\
11 \\
12\end{array}$ & $\begin{array}{l}8 \\
8 \\
8 \\
8\end{array}$ & $\begin{array}{l}20 \\
20 \\
20 \\
10\end{array}$ \\
\hline 1000 & 2,560 & 20,480 & 40 & 1,280 & $\begin{array}{l}13 \\
14 \\
15 \\
16 \\
17\end{array}$ & $\begin{array}{l}13 \\
13 \\
13 \\
13 \\
13\end{array}$ & $\begin{array}{l}80 \\
80 \\
40 \\
40 \\
20\end{array}$ \\
\hline 1003 & 40 & 320 & 一 & 一 & $\begin{array}{l}18 \\
19 \\
20\end{array}$ & $\begin{array}{l}13 \\
13 \\
13\end{array}$ & $\begin{array}{l}40 \\
20 \\
10\end{array}$ \\
\hline 1006 & 80 & 160 & 320 & 2,560 & $\begin{array}{l}21 \\
22 \\
23\end{array}$ & $\begin{array}{l}13 \\
13 \\
13\end{array}$ & $\begin{array}{l}80 \\
40 \\
20\end{array}$ \\
\hline
\end{tabular}

$A=$ agglutinating antibody $; \mathrm{NA}=$ non-agglutinating antibody.

Samples of serum were taken from groups of the chicks on the 1st, 8th or 13th day after hatching and were tested for agglutinating and non-agglutinating antibodies; the results are shown in Table 4. Non-agglutinating antibody alone was observed in the sera of all the twenty-three chicks. The absence of agglutinins in these sera may be partly accounted for by the low agglutinin titres of egg yolks indicated by the antibody levels in related eggs. In the case of chicks from hen no. 1006, which were tested at 13 days of age, agglutinins may have been present in the sera soon after hatching and may have disappeared by the 13th day. Yolk titres related to chicks tested on the 1st 
and 8th days after hatching were lower than yolk titres related to the 13-day-old chicks, which may have been responsible for the little variation in non-agglutinating antibody titres in the sera from different ages of chicks.

(2) Second experiment. A group of hens recently inoculated intravenously with killed Salm. pullorum was used for the production of eggs; chicks were hatched from these eggs and blood samples were taken at intervals. In a few cases two samples were taken from individual chicks when they were between

Table 5. Antibody titres in the sera of young chicks hatched from eggs of immune birds

\begin{tabular}{|c|c|c|c|c|c|c|c|c|}
\hline \multirow{2}{*}{$\begin{array}{l}\text { No. of } \\
\text { parent } \\
\text { bird }\end{array}$} & \multicolumn{2}{|c|}{ Parent serum } & \multicolumn{2}{|c|}{ Parent yolk } & \multirow{2}{*}{$\begin{array}{l}\text { No. of } \\
\text { chick }\end{array}$} & \multirow{2}{*}{$\begin{array}{c}\text { Age of } \\
\text { chick } \\
\text { (days) }\end{array}$} & \multicolumn{2}{|c|}{ Chick serum } \\
\hline & $\mathbf{A}$ & $\mathbf{N A}$ & $\mathbf{A}$ & NA & & & $\mathbf{A}$ & $\mathbf{N A}$ \\
\hline 918 & $\begin{array}{l}2,560 \\
2,560 \\
2,560\end{array}$ & $\begin{array}{l}>2,560 \\
>2,560 \\
>2,560\end{array}$ & $\begin{array}{l}1,280 \\
2,560 \\
2,560\end{array}$ & $\begin{array}{r}5,120 \\
>2,560 \\
>2,560\end{array}$ & $\begin{array}{l}1 \\
2 \\
3\end{array}$ & $\begin{array}{l}1 \\
1 \\
1\end{array}$ & $\begin{array}{r}320 \\
80 \\
20\end{array}$ & $\begin{array}{l}>320 \\
>80 \\
\text { nt }\end{array}$ \\
\hline 919 & 320 & 320 & 320 & 2,560 & 4 & 1 & 2,560 & 10,240 \\
\hline 923 & 1,280 & 2,560 & 1,280 & 2,560 & 5 & 1 & 640 & 2,560 \\
\hline 913 & - & 一 & - & 一 & 6 & 3 & 5 & 40 \\
\hline 914 & 1,280 & 2,560 & 320 & 1,280 & 7 & $\begin{array}{l}1 \\
3\end{array}$ & $\begin{array}{r}1,280 \\
80\end{array}$ & $\begin{array}{r}10,240 \\
320\end{array}$ \\
\hline 924 & 20 & 80 & 20 & 40 & 8 & $\begin{array}{r}3 \\
17\end{array}$ & $\begin{array}{l}0 \\
0\end{array}$ & $\begin{array}{r}40 \\
0\end{array}$ \\
\hline & 20 & 80 & 20 & 40 & 9 & $\begin{array}{r}3 \\
17\end{array}$ & $\begin{array}{l}5 \\
0\end{array}$ & $\begin{array}{l}80 \\
10\end{array}$ \\
\hline 916 & 320 & 640 & 80 & 320 & 10 & $\begin{array}{r}3 \\
17\end{array}$ & $\begin{array}{r}80 \\
0\end{array}$ & $\begin{array}{l}160 \\
160\end{array}$ \\
\hline & 320 & 640 & 80 & 320 & 11 & $\begin{array}{r}7 \\
14\end{array}$ & $\begin{array}{l}5 \\
0\end{array}$ & $\begin{array}{l}20 \\
10\end{array}$ \\
\hline
\end{tabular}

1 and 17 days of age; in others, not more than one sample was taken from each chick. The results are given in Table 5 and show that in contrast to the first experiment agglutinating as well as non-agglutinating antibodies were present in the sera of the young chicks. The relationship between the titres of chick sera and of related egg yolks was not close. Chick nos. 2 and 3 had low serum titres, while egg yolk titres of the related hen (no. 918) were high. In the case of chick no. 4 the non-agglutinating antibody serum titre was 4 times as high as that in the related yolk. The sera from some chicks which were tested on two occasions showed a rapid fall in the level of antibodies from the 1st to the 3rd days after hatching, and this continued until the 14th to 17 th days when the results were negative.

The experiments on the transference of antibodies from the egg to the embryo and chick are summarized in Fig. 8. This shows the rise of antibody level in embryo serum from the 11th day to the end of incubation. The maximum serum titre appeared on the 1st day after hatching and was slightly higher than the average yolk titre. Non-agglutinating antibody formed a large proportion of the total antibody in most of the serum samples, and in chicks from 8 to 17 days of age it was the only antibody which could be demonstrated. 


\section{Route of absorption of antibodies by the developing embryo and young chick}

It has been shown that the developing embryo absorbs antibodies from the yolk sac during the latter half of the incubation period, and that the concentration in the embryo's serum reaches its maximum at about hatching time. Thereafter, the level of antibodies in the serum of the young chick, which is mostly non-agglutinating in nature, rapidly declines. This high proportion of

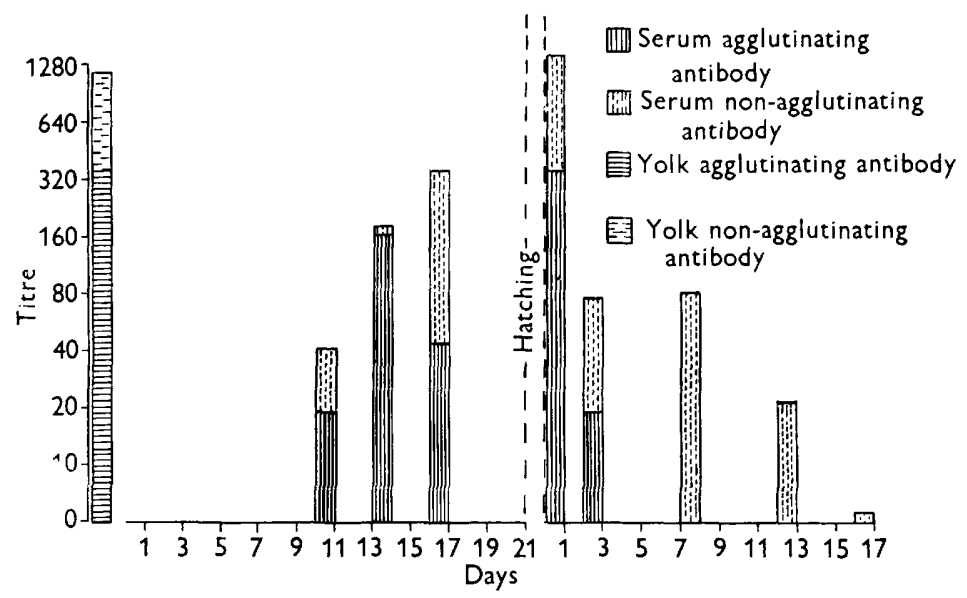

Fig. 8. The transfer of agglutinating and non-agglutinating antibodies from the egg yolk to the developing embryo and young chick.

non-agglutinating antibody which occurs when the total antibody level is being reduced may be associated with the protein metabolism of the chick, and with the route of absorption of yolk by the embryo and newly hatched chick.

The contents of the yolk sac are the main source of food supply for the developing embryo, and according to Lillie (1927) yolk is absorbed through the walls of the yolk sac into the vitelline circulation, and finally to the liver by way of the hepatic blood vessels. The yolk sac is connected to the duodenum by the so-called yolk stalk, and Calhoun (1933) and Kar (1947) have shown that this stalk is hollow, and may help in the absorption of yolk by the embryo, although the yolk material does not pass into the intestines of the chick. Masurier, Branion \& Marcellus (1946) observed the rate of absorption of yolk material by the young chick, and reported that chicks of 5 weeks old contained unabsorbed yolk material. In some chicks the yolk sac was attached to the intestines by the stalk and in others the stalk had either disappeared or was in various stages of atrophy. In the opinion of these authors: 'It would seem that chicks have the ability to absorb the yolk regardless of whether or not the yolk stalk remains attached to the yolk sac.'

Two small experiments designed to find out whether antibodies in egg yolk were absorbed by either $(a)$ the vitelline circulation, or $(b)$ by the intestines via the yolk stalk or by both these routes, are described below. 
(a) Each of six embryos was inoculated into the yolk sac on the 8th day of incubation, with $\mathbf{0 . 4} \mathrm{ml}$. of adult hen serum having an agglutinating titre of $1 / 640$ to Salm. gallinarum. The eggs were then re-incubated and four of them hatched. Serum samples from these four chicks were taken 3 days after hatching and tested for agglutinins. One sample had a titre of 1/20 and the remaining three had titres of $1 / 10$. The average size of an unincubated egg yolk is $\mathbf{1 7 \cdot 1} \mathrm{ml}$. (Romanoff \& Romanoff, 1949), and the inoculation of $\mathbf{0 . 4} \mathrm{ml}$. of serum into the yolk sac would give a dilution of at least $1 / 40$ of the original serum. The dilution of this serum with an agglutinin titre of $1 / 640$ would reduce the titre to about $1 / 15$; this agrees closely with the results obtained. This experiment was made before the rate of the fall of antibodies in chick serum had been ascertained, and judging by Fig. 8 it is assumed that the agglutinin titres would have been higher on the first day after hatching.

(b) The alternative route of yolk absorption to the vitelline and hepatic blood vessels is via the intestine; accordingly, each of twelve newly hatched chicks was, on two occasions, given an oral dose of $0.4 \mathrm{ml}$. of hen serum containing antibodies against Salm. pullorum. Blood samples were then taken and examined for agglutinins; the data in Table 6 shows the low antibody content of the chick sera. The blood volume of the day-old chick is about $2.5 \mathrm{ml}$. and the dilution of the administered serum can be calculated. The results show that only a small proportion of available antibody protein was absorbed by the chick's intestines in a form in which it could be detected by immunological tests. It is apparent from these two experiments that most of the antibody in the egg yolk of young chicks is absorbed by the vitelline and hepatic circulation.

Table 6 . The absorption of antibodies by the young chick after oral administration of immune serum

\begin{tabular}{|c|c|c|c|c|c|c|c|}
\hline \multirow{2}{*}{$\begin{array}{l}\text { No. of } \\
\text { chicks }\end{array}$} & \multicolumn{2}{|c|}{$\begin{array}{c}\text { Titre of } \\
\text { dosing serum }\end{array}$} & \multirow{2}{*}{$\begin{array}{l}\text { Dose } \\
\text { (oral) } \\
\text { (ml.) }\end{array}$} & \multirow{2}{*}{$\begin{array}{c}\text { Age of } \\
\text { chicks } \\
\text { when } \\
\text { dosed } \\
\text { (hr.) }\end{array}$} & \multirow{2}{*}{$\begin{array}{c}\text { Age of } \\
\text { chicks } \\
\text { when } \\
\text { tested } \\
\text { (hr.) }\end{array}$} & \multicolumn{2}{|c|}{$\begin{array}{l}\text { Chick serum titre } \\
\text { (average) }\end{array}$} \\
\hline & A & NA & & & & A & NA \\
\hline 4 & 5,120 & $>5,120$ & $0 \cdot 4$ & 12,30 & $\begin{array}{l}36 \\
48\end{array}$ & $\begin{array}{r}17 \\
8\end{array}$ & $\begin{array}{l}40 \\
10\end{array}$ \\
\hline 4 & 1,280 & $>1,280$ & $0 \cdot 4$ & 36,48 & 60 & 4 & 2 \\
\hline 4 & 1,280 & $>1,280$ & $0 \cdot 4$ & 60,78 & $\begin{array}{l}80 \\
96\end{array}$ & $\begin{array}{l}7 \\
4\end{array}$ & - \\
\hline
\end{tabular}

$A=$ agglutinating antibody $; \mathbf{N A}=$ non-agglutinating antibody.

\section{DISCUSSION}

The passage of antibodies from the hen to its eggs is probably not a simple process of transference of unaltered antibody molecules. The antibody level of eggs laid by hens vaccinated with killed organisms is lower than in eggs from hens naturally infected with Salm. pullorum, and in those vaccinated intravenously there is some alteration to the agglutinin either in its molecular structure or in its relationship to some substance in egg yolk that inhibits 
agglutination. The physiology of the development of the hen's ovule is not well understood, and Conrad \& Scott (1938) have suggested three possible ways by which yolk might be formed. They suggested that in immunized hens, the antibodies either passed directly into the developing ovule, or that on reaching the follicular epithelial cells the globulin molecules were hydrolysed to polypeptides and perhaps peptides. In this state they were then secreted into the ovule where they became reformed into globulin molecules. The amount of globulin in egg yolk is greater (per unit volume) than in serum, and whichever method of globulin accumulation occurred in egg yolk, a greater concentration of antibodies in yolk than in serum is to be expected; this is similar to the accumulation of antibody in bovine colostrum (Marrack, 1947; McDougall, 1949; Smith \& Holm, 1948).

The route of inoculation of killed bacteria into a laying hen clearly influenced the quantity of antibody subsequently demonstrable in the yolks of eggs. The intravenous route induced equivalent non-agglutinating antibody titres in yolks and related sera; in contrast, subcutaneous and intramuscular inoculations induced little demonstrable antibody in egg yolks. Experimental infection of hens with living bacteria produced relatively high titres in the egg yolks, and it appears as if infection with Salm. gallinarum and intravenous inoculation with killed Salm. pullorum enables the bacteria to come into direct contact with ovarian tissue, and the hen's ovary is a common site of infection with these bacteria. These results suggest that some of the antibody in egg yolk may have been produced by ovarian tissue, and that a small proportion only of the circulatory antibody produced in other organs was absorbed by the developing ovules.

No clear relationship between agglutinating and non-agglutinating antibodies has been observed, and their relative proportions in serum and in yolk bear no relationship to each other. There is no evidence to suggest that non-agglutinating antibodies are derived from agglutinins passing through the follicular epithelium into the developing ovule. On the contrary, the identification of agglutinins in yolk at a time when non-agglutinating antibodies alone are demonstrable in related serum, suggests that some of these agglutinins are formed from constituents of protein molecules in the follicular epithelial cells or in the developing ovules.

Jukes \& Kay (1932) found that proteins form $3 \cdot 1 \mathrm{~g}$, of a total of $9 \cdot 4 \mathrm{~g}$. organic matter of hen's egg, and according to Romanoff \& Romanoff (1949) $16.6 \%$ of egg yolk consists of protein. Eagle (1932) and Follensby \& Hooker (1939) have shown that an agglutination reaction may be delayed or even inhibited when proteins other than those directly associated with antigenantibody reactions are present. It was to be expected that the high concentration of protein in egg yolks would result in relatively greater concentrations of demonstrable antibody in yolk than in the serum of immune birds, and that the proteins not associated with antigen-antibody reactions would inhibit agglutination but would not interfere with the sensitization of antigen with antibody. Under these conditions non-agglutinating antibody in egg yolks would combine with antigenic constituents similar to those which combine 
with agglutinins, and this similarity would be demonstrated by a suitable 'blocking test'. In experiments not yet published, no such similarity between agglutinins and non-agglutinating antibodies has been found either in egg yolk or in serum; these confirm the findings of Morgan \& Schütze (1946) who examined the properties of non-agglutinating antibodies against Salm. typhi and Shigella shigae in human sera.

Antibodies against Salm. pullorum transferred to the egg, increase in concentration in the sera of embryos during incubation and rapidly decrease in the sera of young chicks after hatching. Agglutinins disappear more rapidly than non-agglutinating antibodies, and these alone persisted from the 8 th to the 17 th days after hatching. Moore, Shen \& Alexander (1945) examined the plasma of developing chick embryos and showed that during embryonic development the plasma underwent a gradual differentiation from a simple to a more complex pattern, associated with the inclusion in the plasma of various constituents of egg yolk. Schechtman \& Nace (1950) and Marshall \& Deutsch (1950) confirmed these results and have shown that the egg yolk constituents in the serum disappear from about the 5th day after the chick has hatched. Brandt, Clegg \& Andrews (1951) examined the protein constituents of serum of male and female chicks of 4-7 weeks of age and older by electrophoretic and salt-fractionating methods. The $\beta$-globulin and albumin fractions remained unchanged during the period of observation, but the $\alpha$ - and $\gamma$-globulin fractions increased with age. They also identified a fastmoving component which was present in the sera of laying hens but not in the sera of young pullets or male birds.

The transfer of antibodies from mother to young in mammals occurs either during intra-uterine life or by way of the colostrum and the intestines of the newborn. In the rabbit, however, it has been shown (Brambell, Hemmings \& Henderson, 1951) that the route of absorption is by the uterine lumen and the yolk-sac splanchnopleur. This passage of antibodies through the vitelline circulation of the yolk-sac splanchnopleur is comparable to the route of transfer of antibodies from the egg yolk to the developing avian embryo.

The developing avian embryo is supplied with protein and the proteolytic enzymes in the yolk and the embryo render this protein readily available. There is practically no alteration in the quantity or type of antibody transferred from the yolk to the embryo, and in the young immune chick, the digestion of certain protein fractions corresponds with a reduction in circulating antibody. Agglutinins disappear during the first few days after hatching, and from about the 8th to the 17th days non-agglutinating antibodies only are demonstrable. These conditions suggest that non-agglutinating antibodies may be more resistant to breakdown by proteolytic enzymes than agglutinins. It has been shown (Buxton, 1951) that under suitable conditions the treatment of agglutinins with a proteolytic enzyme results in the alteration of the demonstrable antibody into the non-agglutinating type.

I wish to express my appreciation to Dr R. F. Gordon, Director, Poultry Research Station of the Animal Health Trust, for his interest and encouragement, and to Prof. W. I. B. Beveridge, Department of Animal Pathology, Cambridge, for his 
helpful criticisms and for providing laboratory accommodation for part of the work. I am most grateful to Mrs N. Sidery, Miss Sheila Day and Mr P. Brown for their technical assistance.

\section{REFERENCES}

Andrewes, C. H. (1939). Occurrence of neutralising antibodies for Rous sarcoma virus in sera of young 'normal' chicks. J. Path. Bact. 48, 225.

Beveridge, W. I. B. \& Burnet, F. M. (1946). The cultivation of viruses and rickettsiae in the chick embryo. Spec. Rep. Ser. med. Res. Coun., Lond. no. 256.

Brambell, W. F. R., Hemmings, W. A. \& Henderson, M. (1951). Antibodies and Embryos. London: Athlone Press.

Brandey, C. H., Moses, H. E., Jungherr, E. L., Jones, E. E. \& Tizzer, E. E. (1946). Newcastle disease and fowl plague investigations in the war research programme. J. Amer. vet. med. Ass. 108, 369.

Brandt, L. W., ClegG, R. E. \& Andrews, A. C. (1951). The effect of age and degree of maturity on the serum proteins of the chicken. J. biol. Chem. 191, 105.

Buxton, A. (1951). Transfer of bacterial antibodies from the hen to the chick. Nature, Lond. 168, 657.

Calhoun, M. L. (1933). The microscopic anatomy of the digestive tract of Gallus domesticus. Iowa St. Coll. J. Sci. 7, 261.

Conrad, R. M. \& ScotT, H. M. (1938). The formation of the egg of the domestic fowl. Physiol. Rev. 18, 481.

EAGLe, H. (1932). Specific agglutination and precipitation. II. Velocity of reaction. J. Immunol. 23, 153.

Follensby, E. M. \& Hooker, S. B. (1939). The effect of temperature upon combination and aggregation and equilibrium in reaction between antigen and antibody. J. Immunol. 37, 367.

Frank, N. A. \& Edgingron, B. H. (1937). Agglutinin content of eggs from Salmonella pullorum infected hens. Poult. Sci. 16, 442.

Fraser, D. T., Jukes, T. H., Branion, H. D. \& Halpern, K. C. (1934). The inheritance of diphtheria immunity in ducks. J. Immunol. 26, 437.

GarineI, V. (1945). Lack of transmission of immunity through the egg in fowl plague. Clin. vet., Milano, 68, 18.

Grasset, E. G. (1929). Recherches sur la sensibilité du tissu embryonnaire aux antigènes. Essais d'immunisation comparée de l'embryon de poulet et de la poule adulte. C.R. Soc. Biol., Paris, 101, 1102.

Hofstad, M. S. \& Kenzy, S. G. (1950). Susceptibility of chicks hatched from recovered hens to infectious bronchitis. Cornell Vet. 40,87.

Jukes, T. H., Fraser, D. T. \& Orr, M. D. (1934). The transmission of diphtheria antitoxin from hen to egg. J. Immunol. 26, 353.

JukEs, T. H. \& KAY, H. D. (1932). Egg yolk proteins. J. Nutrit. 5, 81 .

Jungherr, E. L. \& Terreli, N. L. (1948). Naturally acquired passive immunity to infectious bronchitis in chicks. Amer. J. vet. Res. 9, 201.

Kar, A. B. (1947). Fate of the yolk-stalk in the domestic fowl. Poult. Sci. 26, 108.

Levine, P. P. \& Fabricant, J. (1950). Susceptibility to Newcastle disease infection of chicks with congenital serum antibodies. Cornell Vet. 40, 213.

Lillie, F. R. (1927). The Development of the Egg. New York: Henry Holt.

MaCDougald, E. I. (1949). An immune globulin fraction from bovine precolostrum. Biochem. J. 44, 531.

Marrack, J. R. (1947). Lactation: function and product. Antibodies in milk. Brit. med. Bull. 5, 187.

Marshali, M. E. \& Deutsch, H. F. (1950). Some protein changes in fluids of the developing chicken embryo. J. biol. Chem. 185, 155. 
Masurier, H. E. Le, Branion, H. D. \& Marcellus, F. N. (1946). Observations on unabsorbed yolk in chicks. Poult. Sci. 25, 300.

Moore, D. H., Shen, S. C. \& Alexander, C. S. (1945). The plasma of developing chicks and pig embryos. Proc. Soc. exp. Biol., N.Y. 58, 307.

Morgan, W. T. J. \& Schütze, H. (1946). Non-agglutinating antibody in human antisera to Sh. shiga and S. typhi. Brit. J. exp. Path. 27, 286.

Ramon, G. (1928). Sur le passage de la toxine et de l'antitoxine tétanique de la poule à l'œuf et au poussin. C.R. Soc. Biol., Paris, 99, 1476.

Romanoff, A. L. \& Romanoff, A. J. (1949). The Avian Egg. New York: J. Wiley and Sons.

Schechtman, A. M. \& Nace, G. (1950). Development of serum proteins in the embryonic chick. Anat. Rec. 106, 436.

Schmidt, S., Ørskov, J. \& Steinberg, E. (1936). Immunisation active contre la peste aviare. Biol. Medd., Kbh. 12, 1.

Sмiтн, E. L. \& Holm, A. (1948). The transfer of immunity to the newborn calf from colostrum. J. biol. Chem. 175, 349.

Storlowa, E. R. (1938). Die Dotteragglutination bei der Kükenruhr. Z. InfektKr. Haustiere, 53, 236.

(Received 22 March 1952) 